\title{
Oil Uptake and Polycyclic Aromatic Hydrocarbons (PAH) in Fried Fresh-Cut Potato: Effect of Cultivar, Anti-Browning Treatment and Storage Conditions
}

\author{
Sandra Balbino ${ }^{1}$, Maja Repajić ${ }^{1, * \mathbb{C}}$, Tea Solarić ${ }^{1}$, Draženka Dite Hunjek ${ }^{2}$, Dubravka Škevin ${ }^{1}$, \\ Klara Kraljić ${ }^{1}$, Marko Obranović ${ }^{1}$ (D) and Branka Levaj ${ }^{1}$ \\ 1 Faculty of Food Technology and Biotechnology, University of Zagreb, Pierottijeva 6, 10000 Zagreb, Croatia; \\ snedjer@pbf.hr (S.B.); teasolaric@gmail.com (T.S.); dskevin@pbf.hr (D.Š.); kkraljic@pbf.hr (K.K.); \\ mobran@pbf.hr (M.O.); branka.levaj@pbf.unizg.hr (B.L.) \\ 2 Intersnack Adria Ltd., Pepe Bukača 11, 43284 Hercegovac, Croatia; drazenka.dite@intersnack.hr \\ * Correspondence: maja.repajic@pbf.unizg.hr
}

Received: 24 September 2020; Accepted: 10 November 2020; Published: 13 November 2020

\begin{abstract}
This work examined the influence of cultivar, anti-browning treatment, package atmosphere and storage duration on the oil uptake and polycyclic aromatic hydrocarbons (PAH) levels in fried fresh-cut potato (FCP). Birgit and Lady Claire potato slices were pre-treated with sodium chloride solution (1\%) and sodium ascorbate solution $(2 \%)$, packaged in vacuum and modified atmosphere and stored at $10^{\circ} \mathrm{C} / 8$ days. Oil uptake was significantly higher in Birgit FCP and was not affected by minimal processing. HPLC analysis/fluorescence detection was able to identify a total of $14 \mathrm{PAH}$. Benzo(a)pyrene and $\Sigma$ PAH4 levels ( 0.62 and $1.36 \mu \mathrm{g} \mathrm{kg}^{-1}$, respectively) were below the EU limits in all fried FCP samples. Majority of examined light and heavy PAH were higher in Lady Claire, while naphthalene, fluorene and pyrene were decreased by vacuum packaging. No differences in PAH levels were noted in FCP fried at the beginning and after 2, 4 and 8 days of storage.
\end{abstract}

Keywords: fresh-cut potato; Birgit; Lady Claire; frying; oil uptake; PAH; benzo(a)pyrene

\section{Introduction}

Market segment of busy consumers, which demand convenient and easy-to-use food products, is evermore increasing [1]. On the other hand, there is a growing perception of industrially processed foods and ready meals being less "natural" and "unhealthy" [2]. This large gap is recently being addressed by the food industry through the production of minimally processed or fresh-cut (FC) food products. Besides convenience, FC products also offer preserved nutritive value and prolonged freshness [3,4].

With 2017 global production of around 390 million tonnes and cultivation area of almost 8 million ha, potato (Solanum tuberosum L.) is still the most widely consumed vegetable and one of the world's largest food crops, third only to rice and wheat [5]. As the consumer demand for FCP is steadily increasing and new products are being launched on the market, there is also a growing scientific interest for the appropriate potato cultivars and treatments that will enable prolonged shelf-life of such products [6]. Therefore, various anti-browning treatments and storage conditions used to prevent the appearance of negative colour changes and to maximally extend the shelf-life have been investigated [7-12]. Furthermore, physiological aging of FC product due to respiration could be delayed with storage under decreased oxygen level, e.g., vacuum (VP) or modified atmosphere packaging (MAP) [9]. Similar results were obtained in our previous study [13] where VP and MAP in comparison with packaging in the passive atmosphere (more abundant with oxygen) on durability of FCP were examined. 
In addition, as most potatoes are consumed fried in the form of French fries or chips [14], it is important to determine the influence of FC processing and storage conditions on the nutritional value and safety of such products. Since these innovative processing, packaging and preparation methods place these products in the novel food group as determined by EFSA through the EU Regulation $2015 / 2283$, thorough risk assessment is necessary in order to enable their safe consumption [15]. One of the major health risks connected with the consumption of fried foods in general is its oil uptake. The amount of absorbed oil is increased by the higher surface/volume ratio, lower dry matter content and lower frying temperatures [16-18].

In addition, food processed by frying in general, as well as French fries and potato chips are often related to elevated levels of heat-induced toxic chemicals such as acrylamide, furans and PAH [19]. PAH represent a large group of ubiquitous contaminants composed of 2 or more aromatic rings and are formed by incomplete burning of organic matter. Their toxicity increases by the number of rings according to which they can be classified as light fraction (2-4 rings) and heavy fraction (containing more than 4 rings). PAH contamination of food occurs by the means of environmental pollution as well as heat processing [20]. Genotoxic and mutagenic activity of PAH is often attributed to the heavy fraction, while their light fraction can cause systemic toxic effects [21]. PAH in fried food can originate from raw food, frying oil and frying itself, however, considering that refined vegetable oil is used for frying and replaced on regular basis, PAH appearance can be linked to cultivar properties, growth conditions and post-harvest processing [22-25]. EU Regulation 835/2011 amending Regulation $1881 / 2006$ set new limits for the concentration of PAH in food [26]. Maximum limit of $2 \mu \mathrm{g} \mathrm{kg}^{-1}$ in oils for human consumption or used as ingredients for benzo(a)pyrene was complemented by the sum of so called PAH4 (benzo(a)pyrene, benzo(a)anthracene, benzo(b)fluoranthene and chrysene) set to $10 \mu \mathrm{g} \mathrm{kg}{ }^{-1}$.

Based on the background described above, this study aimed to access the influence of the cultivar, anti-browning treatment as well as packaging atmosphere and storage duration on the oil uptake and the content of PAH contaminants in fried FCP slices.

\section{Materials and Methods}

\subsection{Materials}

Applied experimental setup and FCP preparation procedure derived from the results of previous studies through which the most satisfactory packaging (films for VP and MAP) as well as storage conditions (temperature) and duration (up to 8 days) were selected based on microbiological and sensory assays [13]. Briefly, potatoes (Solanum tuberosum cv. Birgit and Lady Claire) grown in Croatia (Slavonia, $45^{\circ} 40^{\prime} \mathrm{N}, 17^{\circ} 1^{\prime} \mathrm{E}$ ) were used for the experiment. After harvesting, tubers were stored in the dark at $8{ }^{\circ} \mathrm{C} / 100 \% \mathrm{RH}$ and 3 days before processing at $16{ }^{\circ} \mathrm{C}$. Uniform and undamaged tubers with diameter greater than $35 \mathrm{~mm}$ were hand-peeled, tap water washed and cut into $5 \mathrm{~mm}$ thick slices using commercial cutting machine (MCM62020-CNCM30, Multitalent, Robert Bosch d.o.o., Škofja Loka, Slovenia). Immediately after cutting, slices were inspected for absence of visual defects and immersed for $3 \mathrm{~min}$ in sodium chloride $(1 \%, w / v)$ (Solana d.d., Tuzla, Bosnia and Herzegovina) or sodium ascorbate $(2 \%, w / v)$ (Nutrimedica d.o.o., Zagreb, Croatia) with sample/solution ratio of $1: 4(w / v)$. Slices were then strained using stainless steel colander to reduce the water content and packaged (300 g) using two different packaging methods: VP and MAP $\left(10.0 \% \mathrm{CO}_{2}, 3.0 \% \mathrm{O}_{2}, 87.0 \% \mathrm{~N}_{2}\right)$. For VP samples polyamide/polyethylene (PA/PE) bags with film thickness $90 \mu \mathrm{m}$ (permeability at $23^{\circ} \mathrm{C}$ and $\mathrm{RH} \%$ for $\mathrm{O}_{2}$ was $8.21 \mathrm{~cm}^{3} \mathrm{~m}^{-2}$ day $^{-1} \mathrm{bar}^{-1}$ ) were used and MAP was carried out in PA/PE bags with film thickness $75 \mu \mathrm{m}$ (permeability for $\mathrm{O}_{2}$ was $22.3 \mathrm{~cm}^{3} \mathrm{~m}^{-2}$ day $^{-1} \mathrm{bar}^{-1}$ ) [27]. The samples undergoing VP were sealed by exclusion of air from the bags using vacuum sealer (WS110W vacuum packager, Gorenje, Velenje, Slovenia), while MAP was achieved by gas mixture injection with Junior Digit device (Besser Vacuum, Dignano, Italy). All samples were stored at $10^{\circ} \mathrm{C} / 8$ days. For analytical purposes, initially and after 2, 4 and 8 days, $180 \mathrm{~g}$ of raw slices were fried in $1.5 \mathrm{~L}$ of refined sunflower 
oil at $180^{\circ} \mathrm{C} / 5$ min using commercial fryer (FR490070, Tefal, Rumilly, France). After frying, excess oil was absorbed by paper towels, fried slices were cooled at ambient temperature and stored at $-20^{\circ} \mathrm{C}$ until further analysis. For analysis purpose, dry matter of the raw potatoes was determined by drying at $103 \pm 2{ }^{\circ} \mathrm{C}$ to constant mass [28].

\subsection{Oil Extraction}

Representative sample (50 g) of fried potato slices, for each factor combination, were mashed into puree using pestle and mortar. Prepared purees $(10 \mathrm{~g})$ were placed in Erlenmeyer flask and extracted with $30 \mathrm{~mL}$ of hexane in ultrasonic bath (RK $100 \mathrm{H}$, Bandelin electronic GmbH \& Co., Berlin, Germany) for $60 \mathrm{~min}$. Obtained suspension was filtered through Whatman filter paper which was afterwards rinsed by 3 portions of hexane $\left(10 \mathrm{~mL}\right.$ each) and solvent was removed on a rotary evaporator at $40{ }^{\circ} \mathrm{C}$ and 300 mbar [29]. Extracted lipid fraction was stripped of the remaining solvent under the flow of nitrogen and afterwards weighed. Determined weight was used to assess the oil uptake during frying. Extracted lipids were then dissolved to $1 \mathrm{~mL}$ with cyclohexane and used for HPLC determination of PAH.

\subsection{PAH Isolation and Determination}

PAH isolation was performed by donor-acceptor complex chromatography (DACC) that was previously developed by Neđeral et al. (2013) [30]. HPLC pump (Pharmacia LKB Biotechnology AB, Uppsala, Sweden) with $250 \mu \mathrm{L}$ injector loop was employed to load the sample to the Varian Chromspher Pi $80 \times 3 \mathrm{~mm}$ column (Sint-Katelijn-Waver, Belgium). Triacylglycerols were stripped by the elution with iso-propanol at $0.35 \mathrm{~mL} \mathrm{~min}^{-1}$ during $11.5 \mathrm{~min}$. PAH remaining on the isolation column were afterwards back-flushed by secondary HPLC pump (Varian 9010, Varian, Sint-Katelijn-Waver, Belgium) onto the two inter-connected analytical Pursuit 5 PAH $250 \times 4.6 \mathrm{~mm} \times 5 \mu \mathrm{m}$ (Varian, Sint-Katelijn-Waver, Belgium) columns which were heated to $30{ }^{\circ} \mathrm{C}$. After each elution, DACC column was cleaned by iso-propanol at $0.35 \mathrm{~mL} \mathrm{~min}^{-1}$ for $10 \mathrm{~min}$. Water, ethyl-acetate and acetonitrile were used with gradient program shown in Table 1.

Table 1. Gradient program for the separation of PAH.

\begin{tabular}{ccccc}
\hline $\begin{array}{c}\text { Time } \\
(\mathbf{m i n})\end{array}$ & $\begin{array}{c}\text { Flow } \\
\left(\mathbf{m L ~} \mathbf{~ m i n}^{-\mathbf{1}}\right)\end{array}$ & $\begin{array}{c}\text { \%A } \\
\text { (Water) }\end{array}$ & $\begin{array}{c}\text { \% B } \\
\text { (Ethyl-Acetate) }\end{array}$ & $\begin{array}{c}\text { \%C } \\
\text { (Acetonitrile) }\end{array}$ \\
\hline 0 & 0.4 & 20 & 0 & 80 \\
2.49 & 0.4 & 20 & 0 & 80 \\
2.50 & 1 & 20 & 0 & 80 \\
3.90 & 1 & 20 & 0 & 80 \\
17.90 & 1 & 0 & 0 & 100 \\
45.99 & 1 & 0 & 0 & 100 \\
46.00 & 1 & 0 & 30 & 70 \\
68.00 & 1 & 0 & 30 & 70 \\
69.00 & 1 & 0 & 0 & 100 \\
73.00 & 1 & 0 & 0 & 100 \\
83.00 & 1 & 20 & 0 & 80 \\
90.00 & 0.40 & 20 & 0 & 80 \\
\hline
\end{tabular}

Varian Pro Star 363 fluorescence detector (Varian, Sint-Katelijn-Waver, Belgium) running a detection program (Table 2) was used to assess the eluted PAH. Besides oils extracted from fried potato slices, PAH content was also determined in fresh sunflower oil used for frying. 
Table 2. Fluorescence detector program for detection of individual PAH compounds.

\begin{tabular}{cccc}
\hline Time (min) & Excitation $(\mathbf{n m})$ & Emission $(\mathbf{n m})$ & PAH Detected \\
\hline 0.0 & 225 & 320 & - \\
14.5 & 256 & 390 & Fluorene, phenanthrene, anthracene \\
16.7 & 240 & 460 & Fluoranthene \\
18.0 & 240 & 390 & Pyrene \\
19.5 & 270 & 385 & Benzo(a)anthracene, chrysene \\
& & & Benzo(b)fluoranthene, \\
24.0 & 290 & 430 & benzo(k)fluoranthene, benzo(a)pyrene, \\
& & & dibenzo(a,h)anthracene \\
& 305 & 480 & Benzo(g,h,i)perylene, \\
39.0 & 305 & 480 & indeno(1,2,3,-c,d)pyrene \\
55.0 & & & - \\
\hline
\end{tabular}

\subsection{PAH Quantification and Validation}

Calibration and validation were done by spiking of blank oil matrix with 16 EPA PAH standards dissolved in methylene chloride:methanol (1:1) (Supelco, Bellefonte, PA, USA). Phenanthrene, anthracene, pyrene, benzo(a)anthracene, chrysene, benzo(k)fluoranthene and benzo(a)pyrene were calibrated at $0.25-17.5 \mu \mathrm{g} \mathrm{kg}{ }^{-1}$ of lipid fraction, while the calibration ranges used for fluorene, fluoranthene, benzo(b)fluoranthene, benzo(a,h)anthracene and benzo(g,h,i)perylene were $0.5-35 \mu \mathrm{g} \mathrm{kg}^{-1}$. Because of its lower fluorescence, indeno $(1,2,3-\mathrm{c}, \mathrm{d})$ pyrene was calibrated in the range of 1-60 $\mathrm{g} \mathrm{kg}^{-1}$. Linearity was established for all analysed standards with correlation coefficients above 0.999 in the studied range. Limit of detection (LOD) and limit of quantification (LOQ) were determined by the injection of seven blanks spiked with PAH at the lowest level of calibration for each PAH analysed and calculated from the slope of calibration curve (S) and standard deviation of the response $(\sigma)$ as LOD $=3.3 \sigma / S$ and LOQ $=10 \sigma / S$, respectively. LOD and LOQ ranged from $0.04-0.61 \mu \mathrm{g} \mathrm{kg}^{-1}$ and $0.13-1.84 \mu \mathrm{g} \mathrm{kg}$, therefore showing satisfactory sensitivity of the method. Recoveries were $94.1-109.4 \%$, while the repeatability testing showed relative standard deviations $2.7-4.3 \%$, which is considered sufficient based on ICH procedures for validation of analytical methods [31]. All measurements were done with at least two determinations.

\subsection{Statistical Analysis}

For the statistical analysis, full factorial randomized experimental design was employed, where independent categorical variables were: (a) cultivar type (cv. Birgit and Lady Claire), (b) anti-browning agent [sodium chloride (1\%), sodium ascorbate $(2 \%)],(\mathrm{c})$ package atmosphere (VP, MAP) and (d) storage time (0, 2, 4 and 8 days), while oil uptake and determined PAH compounds were dependent continuous variables. Total number of 32 samples (sub-sets of 16 samples for each cultivar, anti-browning agent, package atmosphere and 8 samples for each day) were included in the study and multifactorial analysis of variance followed by post-hoc Tukey's test as well as Principal Component Analysis (PCA) was performed by XLSTAT software at the $p \leq 0.05$ significance level. Statistical analysis was done with replicates included and its results are shown as least square mean \pm standard error (SE).

\section{Results and Discussion}

\subsection{Oil Uptake}

Considering that water is replaced by oil during frying, potato cultivars with higher dry matter content were shown to absorb less oil [32]. Ziaiifar (2008) [33] found that oil intake of fried potatoes is also affected by pre-treatments such as blanching, air drying, osmotic dehydration, steam frying, and coating application such as starch, gelatine, protein, carboxymethyl cellulose, etc. In addition, 
oil uptake is dependent on the thickness and shape of fried potatoes as potato chips can contain up to $40 \%$ of oil, while French fries contain less than $15 \%$.

In this work, weight of oil extracted from fried potato slices during PAH analysis were expressed as a percentage of fried potato weight and used to assess the influence of cultivar, anti-browning pre-treatment and storage conditions on the oil uptake (Figure 1).
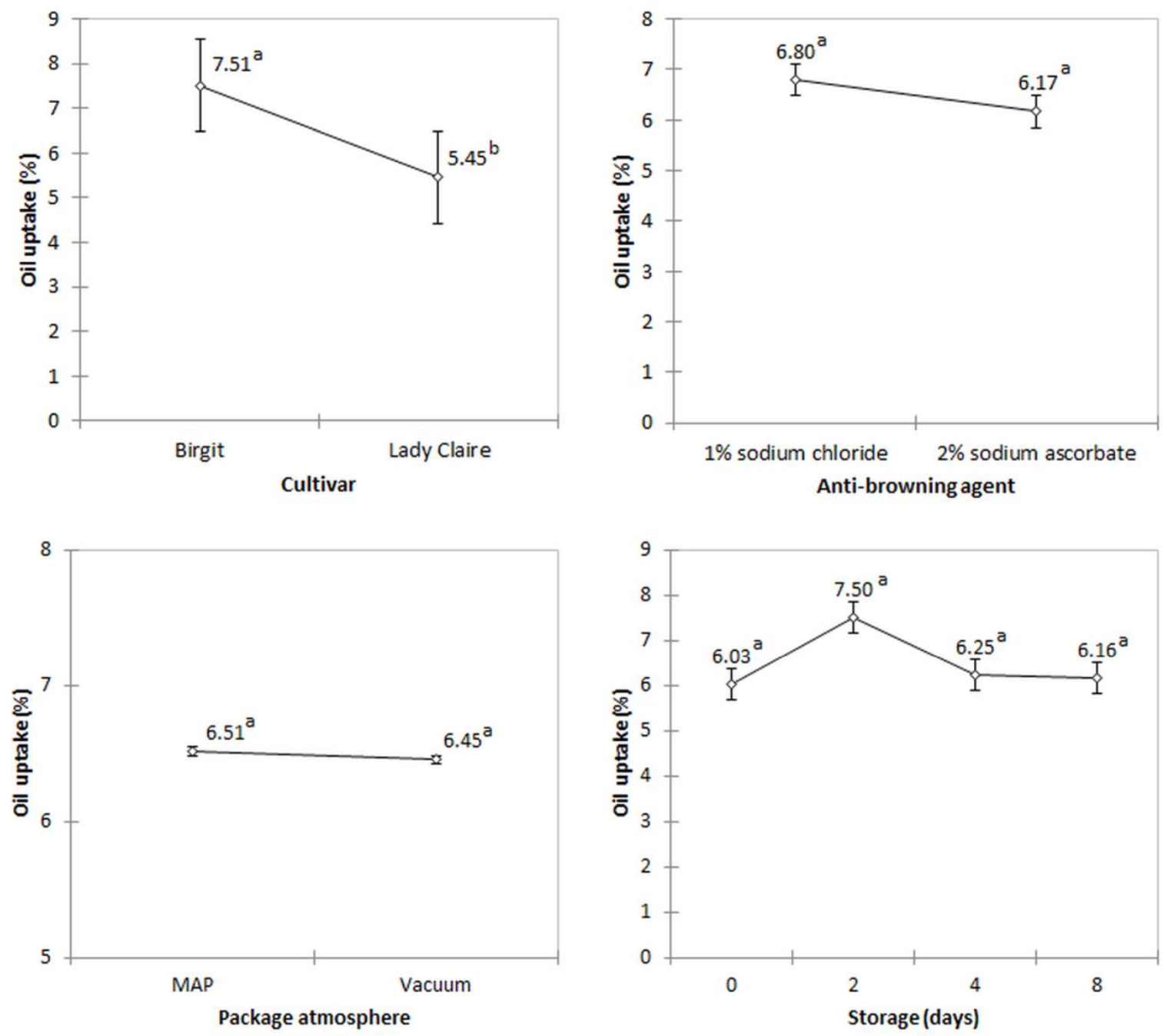

Figure 1. Oil uptake in fried fresh-cut potato as affected by cultivar, anti-browning agent, packaging and storage duration. Results are expressed as mean \pm SE of $n=16$ for cultivars, anti-browning agents, package atmospheres and $n=8$ for days. Values with different letters are statistically different at $p \leq 0.05$.

Oil content was somewhat lower than previously determined by Ziaiifar (2008) [33] and it ranged from $5.34-11.22 \%$ of total weight with an average of $6.48 \%$. Potato slices analysed in this work were $5 \mathrm{~mm}$ thick and their area/volume ratio was lower than in standard industrial chips, which can explain lower oil uptakes. Oil uptake was significantly influenced only by cultivar $(p<0.01)$, while anti-browning pre-treatment with sodium chloride and sodium ascorbate as well as packaging conditions (VP and MAP) and storage time did not cause significant differences. Fried potato slices produced from cv. Birgit had higher oil content than those from cv. Lady Claire (7.51 and 5.45\%, respectively). Considering that the dry matter content between cv. Birgit and Lady Claire were significantly different at $p<0.01(18.45 \%$ and $24.21 \%$, respectively), these results were well expected. Elfnesh et al. (2011) [34] recommend that cultivars with more than $19.5 \%$ of dry matter should be used 
to produce French fries, while potato chips should be prepared from cultivars with dry matter content higher than $20 \%$.

In addition, the results deriving from this work are in line with those obtained by other authors that investigated the influence of FC processing on oil uptake in fried potatoes. Oner and Walker (2010) [35] blanched potato strips at $60{ }^{\circ} \mathrm{C}$ in $0.5 \% \mathrm{CaCl}_{2}$ solution for $20 \mathrm{~min}$, cooled to $20^{\circ} \mathrm{C}$ and re-blanched with water at $98^{\circ} \mathrm{C}$ for $5 \mathrm{~min}$. The potato strips prepared in this way were treated with ozone gas, sodium metabisulphite solution, etc., packaged under near-aseptic conditions or in vacuum and stored at $7 \pm 1{ }^{\circ} \mathrm{C}$ for 28 days. Results for FCP when compared to frozen commercial fries showed significantly lower oil uptake after frying, i.e., $7.9-8.2 \%$ and $21.6 \%$, respectively. No significant differences were however observed between the content of absorbed oil and the way the FCP were treated.

On the other hand, Krokida et al. (2001) [36] showed that immersing or spraying raw potatoes with $40 \%$ sucrose and $20 \%$ sodium chloride solution, when applied as a pre-treatment for frying, caused an osmosis dehydration and consequently had a significant effect on the oil absorption. The potatoes treated with sucrose solution had $60 \%$ less oil and the ones treated with sodium chloride solution $35 \%$ less oil than control. Such treatment caused browning after frying and was more pronounced when sucrose solution was applied. Even though their work points out to osmotic dehydration as an effective method of lowering the oil uptake in the fries, conditions used in this study, i.e., 3 min of immersion and low salt concentrations resulted in similar oil uptakes without disrupting the colour of fried slices.

\subsection{PAH Determination}

Used fluorescence detection was able to identify a total of $14 \mathrm{PAH}$. Compared to the recommendations of EFSA (2007) [37] that call for 16 PAH monitoring, acenaphthylene, which is not fluorescent, could not be identified due to the limitations of fluorescence detector. Acenaphthylene and indeno(1,2,3-c,d)perylene were below the methods detection limit in all samples. Out of all detected light PAH compounds, naphthalene was dominant $\left(0.46-8.52 \mu \mathrm{g} \mathrm{kg}^{-1}\right)$ and followed by phenanthrene (ND-5.44 $\mu \mathrm{g} \mathrm{kg}^{-1}$ ), fluoranthene (ND-3.31 $\mu \mathrm{g} \mathrm{kg}^{-1}$ ) and acenaphthene $\left(0.07-3.11 \mu \mathrm{g} \mathrm{kg}^{-1}\right.$ ) with grand mean values being $3.52,1.58,0.97$ and $0.85 \mathrm{\mu g} \mathrm{kg}^{-1}$, respectively (Table 3). These results correspond well to the light fraction range established for the oils extracted from fried potato samples in the work of Purcaro et al. (2006) [29]. In their research naphthalene was also the main PAH compound, followed by phenanthrene, fluoranthene and pyrene.

On the other hand, heavy PAH fraction (Table 4) was dominated by benzo(g,h,i)perylene, benzo(b)fluoranthene, dibenzo(a,h)anthracene and benzo(a)pyrene with respective mean values of $0.38,0.14,0.14$ and $0.13 \mu \mathrm{g} \mathrm{kg}^{-1}$. In addition, maximum determined level of benzo(a)pyrene was $0.62 \mu \mathrm{g} \mathrm{kg}^{-1}$, which is below the limit of $2 \mu \mathrm{g} \mathrm{kg}^{-1}$ set by the EU Regulation 835/2011 [26].

In 2008 the EFSA Panel on Contaminants in the Food Chain (CONTAM) concluded that benzo(a)pyrene alone is not a suitable marker for measuring PAH content in food and proposed that a total of benzo(a)pyrene, chrysene, benzo(b)fluoranthene and benzo(a)anthracene, so called PAH4 group, should be used as additional PAH contamination indicator [38]. Based on this recommendation, EU Regulation 835/2011 [26] therefore set a limit of $10 \mu \mathrm{g} \mathrm{kg}^{-1}$ for the PAH4 group in oils intended for direct consumption or used as a food ingredient. PAH4 content of oils extracted from all analysed fried potato samples was lower than the set limit and varied from $0.28-1.36 \mu \mathrm{g} \mathrm{kg}^{-1}$. Similarly, Purcaro et al. (2006) [29] also found heavy PAH levels in oils extracted from industrial snacks below the EU limits. Furthermore, Kumosani et al. (2013) [39] assessed the contents of pyrene, benzo(a)anthracene, benzo(e)pyrene, benzofluoranthene and benzo(a)pyrene, in conventionally and microwave fried potato samples, and could not detect any of the examined compounds. 
Table 3. Light (2-4 rings) PAH fraction $\left(\mu \mathrm{g} \mathrm{kg}^{-1}\right)$ in fried fresh-cut potato as affected by cultivar, anti-browning agent, packaging and storage duration.

\begin{tabular}{|c|c|c|c|c|c|c|c|c|c|}
\hline Source of Variation & Naphthalene & Acenaphthene & Fluorene & Phenanthrene & Anthracene & Fluoranthene & $\begin{array}{c}\text { Benzo(a)- } \\
\text { Anthracene }\end{array}$ & Chrysene & Pyrene \\
\hline Cultivar & $p<0.01^{*}$ & $p<0.01 *$ & $p<0.01^{*}$ & $p<0.01 *$ & $p=0.58$ & $p=0.34$ & $p<0.01^{*}$ & $p<0.01 *$ & $p<0.01 *$ \\
\hline Birgit & $2.02 \pm 0.36^{b}$ & $1.48 \pm 0.12^{\mathrm{a}}$ & $0.01 \pm 0.05^{b}$ & $0.38 \pm 0.27^{b}$ & $0.32 \pm 0.13^{\mathrm{a}}$ & $1.10 \pm 0.19^{\mathrm{a}}$ & $0.17 \pm 0.02^{b}$ & $0.07 \pm 0.02^{b}$ & $0.02 \pm 0.04^{b}$ \\
\hline Lady Claire & $5.03 \pm 0.36^{\mathrm{a}}$ & $0.22 \pm 0.12^{b}$ & $0.87 \pm 0.05^{\mathrm{a}}$ & $2.79 \pm 0.27^{\mathrm{a}}$ & $0.43 \pm 0.13^{\mathrm{a}}$ & $0.84 \pm 0.19^{\mathrm{a}}$ & $0.40 \pm 0.02^{\mathrm{a}}$ & $0.29 \pm 0.02^{\mathrm{a}}$ & $0.74 \pm 0.04^{\mathrm{a}}$ \\
\hline Anti-browning agent & $p=0.34$ & $p=0.38$ & $p=0.09$ & $p=0.87$ & $p=0.37$ & $p=0.38$ & $p=0.19$ & $p=0.99$ & $p=0.73$ \\
\hline $1 \%$ sodium chloride & $3.78 \pm 0.36^{\mathrm{a}}$ & $0.93 \pm 0.12^{\mathrm{a}}$ & $0.38 \pm 0.05^{\mathrm{a}}$ & $1.62 \pm 0.27^{\mathrm{a}}$ & $0.46 \pm 0.13^{\mathrm{a}}$ & $0.85 \pm 0.19^{\mathrm{a}}$ & $0.26 \pm 0.02^{\mathrm{a}}$ & $0.18 \pm 0.02^{\mathrm{a}}$ & $0.39 \pm 0.04^{\mathrm{a}}$ \\
\hline $2 \%$ sodium ascorbate & $3.26 \pm 0.36^{\mathrm{a}}$ & $0.77 \pm 0.12^{\mathrm{a}}$ & $0.50 \pm 0.05^{\mathrm{a}}$ & $1.55 \pm 0.27^{\mathrm{a}}$ & $0.29 \pm 0.13^{\mathrm{a}}$ & $1.09 \pm 0.19^{\mathrm{a}}$ & $0.31 \pm 0.02^{\mathrm{a}}$ & $0.18 \pm 0.02^{\mathrm{a}}$ & $0.37 \pm 0.04^{\mathrm{a}}$ \\
\hline Package atmosphere & $p=0.04 *$ & $p=0.66$ & $p=0.03 *$ & $p=0.25$ & $p=0.34$ & $p=0.79$ & $p=0.07$ & $p=0.09$ & $p=0.02 *$ \\
\hline Vacuum & $2.92 \pm 0.36^{b}$ & $0.81 \pm 0.12^{\mathrm{a}}$ & $0.36 \pm 0.05^{b}$ & $1.35 \pm 0.27^{\mathrm{a}}$ & $0.28 \pm 0.13^{\mathrm{a}}$ & $1.01 \pm 0.19^{\mathrm{a}}$ & $0.25 \pm 0.02^{\mathrm{a}}$ & $0.15 \pm 0.02^{\mathrm{a}}$ & $0.30 \pm 0.04^{b}$ \\
\hline Modified & $4.12 \pm 0.36^{\mathrm{a}}$ & $0.89 \pm 0.12^{\mathrm{a}}$ & $0.52 \pm 0.05^{\mathrm{a}}$ & $1.82 \pm 0.27^{\mathrm{a}}$ & $0.47 \pm 0.13^{a}$ & $0.94 \pm 0.19^{a}$ & $0.32 \pm 0.02^{a}$ & $0.21 \pm 0.02^{\mathrm{a}}$ & $0.46 \pm 0.04^{\mathrm{a}}$ \\
\hline Storage (days) & $p=0.47$ & $p=0.23$ & $p=0.16$ & $p=0.63$ & $p=0.23$ & $p=0.32$ & $p=0.08$ & $p=0.73$ & $p=0.81$ \\
\hline 0 & $3.10 \pm 0.51^{\mathrm{a}}$ & $0.70 \pm 0.17^{\mathrm{a}}$ & $0.58 \pm 0.07^{\mathrm{a}}$ & $1.81 \pm 0.38^{\mathrm{a}}$ & $0.25 \pm 0.19^{\mathrm{a}}$ & $0.55 \pm 0.26^{\mathrm{a}}$ & $0.31 \pm 0.03^{\mathrm{a}}$ & $0.17 \pm 0.03^{\mathrm{a}}$ & $0.42 \pm 0.06^{\mathrm{a}}$ \\
\hline 2 & $4.20 \pm 0.51^{\mathrm{a}}$ & $1.18 \pm 0.17^{\mathrm{a}}$ & $0.39 \pm 0.07^{\mathrm{a}}$ & $1.33 \pm 0.38^{\mathrm{a}}$ & $0.30 \pm 0.19^{\mathrm{a}}$ & $1.26 \pm 0.26^{\mathrm{a}}$ & $0.34 \pm 0.03^{\mathrm{a}}$ & $0.21 \pm 0.03^{\mathrm{a}}$ & $0.37 \pm 0.06^{\mathrm{a}}$ \\
\hline 4 & $3.24 \pm 0.51^{\mathrm{a}}$ & $0.80 \pm 0.17^{\mathrm{a}}$ & $0.41 \pm 0.07^{\mathrm{a}}$ & $1.33 \pm 0.38^{\mathrm{a}}$ & $0.21 \pm 0.19^{\mathrm{a}}$ & $1.04 \pm 0.26^{\mathrm{a}}$ & $0.23 \pm 0.03^{\mathrm{a}}$ & $0.18 \pm 0.03^{\mathrm{a}}$ & $0.35 \pm 0.06^{\mathrm{a}}$ \\
\hline 8 & $3.55 \pm 0.51^{\mathrm{a}}$ & $0.72 \pm 0.17^{\mathrm{a}}$ & $0.39 \pm 0.07^{\mathrm{a}}$ & $1.87 \pm 0.38^{\mathrm{a}}$ & $0.73 \pm 0.19^{\mathrm{a}}$ & $1.03 \pm 0.26^{\mathrm{a}}$ & $0.25 \pm 0.03^{\mathrm{a}}$ & $0.16 \pm 0.03^{a}$ & $0.38 \pm 0.06^{\mathrm{a}}$ \\
\hline Cultivar $x$ Package atmosphere & $p=0.01 *$ & $p=0.41$ & $p=0.03^{*}$ & $p=0.01 *$ & $p=0.23$ & $p=0.06$ & $p=0.14$ & $p=0.14$ & $p<0.01 *$ \\
\hline Birgit $\times$ Vacuum & $2.26 \pm 0.51^{b}$ & $1.51 \pm 0.17^{\mathrm{a}}$ & $0.01 \pm 0.07^{c}$ & $0.75 \pm 0.38^{b c}$ & $0.34 \pm 0.19^{\mathrm{a}}$ & $1.41 \pm 0.26^{\mathrm{a}}$ & $0.16 \pm 0.03^{b}$ & $0.06 \pm 0.03^{b}$ & $0.05 \pm 0.06^{c}$ \\
\hline Birgit $\times$ Modified & $1.78 \pm 0.51^{\mathrm{b}}$ & $1.44 \pm 0.17^{\mathrm{a}}$ & $0.01 \pm 0.07^{\mathrm{c}}$ & $0.01 \pm 0.38^{c}$ & $0.30 \pm 0.19^{\mathrm{a}}$ & $0.79 \pm 0.26^{\mathrm{a}}$ & $0.18 \pm 0.03^{b}$ & $0.07 \pm 0.03^{b}$ & $0.00 \pm 0.06^{c}$ \\
\hline Lady Claire $\times$ Vacuum & $3.58 \pm 0.51^{\mathrm{b}}$ & $0.11 \pm 0.17^{b}$ & $0.71 \pm 0.07^{b}$ & $1.96 \pm 0.38 \mathrm{bc}$ & $0.21 \pm 0.19^{\mathrm{a}}$ & $0.60 \pm 0.26^{\mathrm{a}}$ & $0.34 \pm 0.03^{\mathrm{a}}$ & $0.24 \pm 0.03^{\mathrm{a}}$ & $0.56 \pm 0.06^{b}$ \\
\hline Lady Claire $\times$ Modified & $6.47 \pm 0.51^{\mathrm{a}}$ & $0.34 \pm 0.17^{b}$ & $1.03 \pm 0.07^{\mathrm{a}}$ & $3.62 \pm 0.38^{\mathrm{a}}$ & $0.64 \pm 0.19^{\mathrm{a}}$ & $1.08 \pm 0.26^{\mathrm{a}}$ & $0.45 \pm 0.03^{\mathrm{a}}$ & $0.35 \pm 0.03^{\mathrm{a}}$ & $0.91 \pm 0.06^{\mathrm{a}}$ \\
\hline Grand mean $(n=32)$ & 3.52 & 0.85 & 0.44 & 1.58 & 0.37 & 0.97 & 0.28 & 0.18 & 0.38 \\
\hline
\end{tabular}

* Statistically significant variable at $p \leq 0.05$. Results are expressed as mean \pm SE of $n=16$ for cultivars, anti-browning agents, package atmospheres and $n=8$ for days and cultivars $\times$ package atmospheres. Values in the same column with different letters are statistically different at $p \leq 0.05$. 
Table 4. Heavy (5 and 6 rings) PAH fraction $\left(\mu \mathrm{g} \mathrm{kg}^{-1}\right)$ in fried fresh-cut potato as affected by cultivar, anti-browning agent, packaging and storage duration.

\begin{tabular}{|c|c|c|c|c|c|}
\hline Source of Variation & $\begin{array}{c}\text { Benzo(b)- } \\
\text { Fluoranthene }\end{array}$ & $\begin{array}{c}\text { Benzo(k)- } \\
\text { Fluoranthene }\end{array}$ & $\begin{array}{l}\text { Benzo(a)- } \\
\text { Pyrene }\end{array}$ & $\begin{array}{l}\text { Dibenzo(a,h)- } \\
\text { Anthracene }\end{array}$ & $\begin{array}{c}\text { Benzo(g,h,i)- } \\
\text { Perylene }\end{array}$ \\
\hline Cultivar & $p<0.01 *$ & $p=0.14$ & $p=0.02 *$ & $p=0.97$ & $p<0.01^{*}$ \\
\hline Birgit & $0.06 \pm 0.02^{b}$ & $0.05 \pm 0.01^{\mathrm{a}}$ & $0.08 \pm 0.03^{b}$ & $0.14 \pm 0.05^{\mathrm{a}}$ & $0.19 \pm 0.06^{b}$ \\
\hline Lady Claire & $0.22 \pm 0.02^{a}$ & $0.08 \pm 0.01^{\mathrm{a}}$ & $0.18 \pm 0.03^{a}$ & $0.14 \pm 0.05^{\mathrm{a}}$ & $0.57 \pm 0.06^{\mathrm{a}}$ \\
\hline Anti-browning agent & $p=0.23$ & $p=0.17$ & $p=0.79$ & $p=0.95$ & $p=0.12$ \\
\hline $1 \%$ sodium chloride & $0.12 \pm 0.02^{\mathrm{a}}$ & $0.06 \pm 0.01^{\mathrm{a}}$ & $0.12 \pm 0.03^{a}$ & $0.14 \pm 0.05^{\mathrm{a}}$ & $0.31 \pm 0.06^{\mathrm{a}}$ \\
\hline $2 \%$ sodium ascorbate & $0.15 \pm 0.02^{\mathrm{a}}$ & $0.08 \pm 0.01^{\mathrm{a}}$ & $0.13 \pm 0.03^{\mathrm{a}}$ & $0.14 \pm 0.05^{\mathrm{a}}$ & $0.45 \pm 0.06^{\mathrm{a}}$ \\
\hline Package atmosphere & $p=0.05^{*}$ & $p=0.66$ & $p=0.19$ & $p=0.76$ & $p=0.14$ \\
\hline Vacuum & $0.11 \pm 0.02^{b}$ & $0.07 \pm 0.01^{\mathrm{a}}$ & $0.15 \pm 0.03^{a}$ & $0.13 \pm 0.05^{\mathrm{a}}$ & $0.45 \pm 0.06^{\mathrm{a}}$ \\
\hline Modified & $0.17 \pm 0.02^{\mathrm{a}}$ & $0.06 \pm 0.01^{\mathrm{a}}$ & $0.10 \pm 0.03^{\mathrm{a}}$ & $0.15 \pm 0.05^{\mathrm{a}}$ & $0.32 \pm 0.06^{\mathrm{a}}$ \\
\hline Storage (days) & $p=0.95$ & $p=0.67$ & $p=0.07$ & $p=0.49$ & $p=0.18$ \\
\hline 0 & $0.13 \pm 0.03^{\mathrm{a}}$ & $0.07 \pm 0.02^{\mathrm{a}}$ & $0.10 \pm 0.04^{\mathrm{a}}$ & $0.13 \pm 0.07^{\mathrm{a}}$ & $0.46 \pm 0.08^{a}$ \\
\hline 2 & $0.15 \pm 0.03^{\mathrm{a}}$ & $0.08 \pm 0.02^{\mathrm{a}}$ & $0.22 \pm 0.04^{a}$ & $0.19 \pm 0.07^{\mathrm{a}}$ & $0.50 \pm 0.08^{a}$ \\
\hline 4 & $0.13 \pm 0.03^{a}$ & $0.05 \pm 0.02^{\mathrm{a}}$ & $0.11 \pm 0.04^{\mathrm{a}}$ & $0.19 \pm 0.07^{\mathrm{a}}$ & $0.29 \pm 0.08^{a}$ \\
\hline 8 & $0.14 \pm 0.03^{\mathrm{a}}$ & $0.07 \pm 0.02^{\mathrm{a}}$ & $0.08 \pm 0.04^{\mathrm{a}}$ & $0.06 \pm 0.07^{\mathrm{a}}$ & $0.27 \pm 0.08^{a}$ \\
\hline Cultivar x Package atmosphere & $p=0.32$ & $p=0.14$ & $p=0.02 *$ & $p=0.81$ & $p=0.21$ \\
\hline Birgit $\times$ Vacuum & $0.04 \pm 0.03^{b}$ & $0.07 \pm 0.02^{\mathrm{a}}$ & $0.15 \pm 0.04^{\mathrm{ab}}$ & $0.16 \pm 0.07^{a}$ & $0.69 \pm 0.08^{a b}$ \\
\hline Birgit $\times$ Modified & $0.07 \pm 0.03^{b}$ & $0.04 \pm 0.02^{\mathrm{a}}$ & $0.00 \pm 0.04^{b}$ & $0.15 \pm 0.07^{\mathrm{a}}$ & $0.45 \pm 0.08^{a b}$ \\
\hline Lady Claire $\times$ Vacuum & $0.18 \pm 0.03^{\mathrm{a}}$ & $0.07 \pm 0.02^{\mathrm{a}}$ & $0.15 \pm 0.04^{\mathrm{ab}}$ & $0.12 \pm 0.07^{\mathrm{a}}$ & $0.20 \pm 0.08^{b}$ \\
\hline Lady Claire $\times$ Modified & $0.26 \pm 0.03^{a}$ & $0.09 \pm 0.02^{\mathrm{a}}$ & $0.20 \pm 0.04^{\mathrm{a}}$ & $0.14 \pm 0.07^{\mathrm{a}}$ & $0.18 \pm 0.08^{b}$ \\
\hline Grand mean $(n=32)$ & 0.14 & 0.07 & 0.13 & 0.14 & 0.38 \\
\hline
\end{tabular}

* Statistically significant variable at $p \leq 0.05$. Results are expressed as mean $\pm \mathrm{SE}$ of $n=16$ for cultivars, anti-browning agents, package atmospheres and $n=8$ for days and cultivars $\times$ package atmospheres. Values in the same column with different letters are statistically different at $p \leq 0.05$.

As PAH contamination of food products can be related to the environmental and processing conditions, $\mathrm{PAH}$ in fried potatoes can originate from the frying oil and frying process but also from the potatoes themselves. In general, oilseeds contain high amounts of triacylglicerols and are, therefore, prone to uptake of lipophilic molecules such as PAH from soils [40,41]. During oil production these PAH, together with the ones that contaminate seeds during post-harvest are extracted to crude oil, however, they are removed by refining [42-44]. Therefore, frying oils are usually not likely to be the main sources of PAH contamination in fried food. PAH analysis performed on the fresh, refined sunflower oil used in this work could not identify any of the examined compounds.

In addition, as several authors concluded that the usual temperatures applied during typical domestic frying, such as $180^{\circ} \mathrm{C}$ that was used in this work, do not induce PAH formation, frying oil and process are not likely to be a source of contamination $[29,45]$.

Hence, since no PAH contamination was detected in the utilized sunflower oil, and frying temperature as well as duration was too short to enable PAH formation, $\mathrm{PAH}$ origin was probably environmental, i.e., related to soil contamination of potatoes. According to Bansal and Kim (2015) [46], compared to other vegetable species, root vegetables such as potatoes uptake more PAH from the contaminated soils. Results on PAH content in fresh potatoes vary significantly between studies of different authors. Ashraf et al. (2012) [47] studied PAH contents in fresh vegetables originating from Saudi Arabia and found the highest levels present in analysed potato samples $\left(11 \mu \mathrm{g} \mathrm{kg}{ }^{-1}\right)$. In general, vegetable skin was more contaminated than the flesh, and contamination was in proportion to the degree of environmental pollution. They concluded that due to the high consumption of potatoes, these levels could represent a significant PAH exposure source. Similar results for vegetables grown in Denmark were found by Samsøe-Petersen et al. (2002) [23]. Wennrich et al. (2002) [24] also found higher total PAH levels $\left(\mu \mathrm{g} \mathrm{kg}^{-1}\right)$ in potatoes when compared to other vegetables, while Zhong and Wang (2002) [25] observed PAH levels in potatoes up to $12.54 \mu^{\mathrm{g} \mathrm{kg}^{-1}}$. In their research Abou-Arab et al. (2014) [22] found approximately $6.2 \mu \mathrm{g} \mathrm{kg}^{-1}$ of total PAH and $2.4 \mu \mathrm{g} \mathrm{kg}^{-1}$ of PAH4. Regardless of the significant PAH levels in fresh potatoes, Purcaro et al. (2006) [29] consider that environmental contamination of potato with PAH does not attribute to its final concentrations in fries because potatoes are being washed and peeled before frying. However, Kulhánek et al. (2005) [48], which assessed the 
human exposure to PAH from vegetable origin, showed that root vegetables represent a dominant diet source of vegetable PAH, even after careful peeling is assumed. Nevertheless, besides adding to the possibility that PAH contamination in fried potatoes is related to the environmental contamination, reported differences in PAH concentrations obtained by various authors indicate that they are affected by the growth conditions, region or cultivar.

\subsection{Effect of Cultivar}

Different authors have shown that some cultivars can be more suitable for FC as they differ in phenolics, ascorbic acid, soluble sugars and polyphenol oxidase activity that affect enzymatic browning $[8,49,50]$. However, during the selection of the most appropriate cultivar, safety of FCP such as acrylamide formation potential [51] and PAH content should also be taken into consideration.

In previous research of Dite Hunjek et al. (2020) [13] cv. Birgit and Lady Claire showed a good potential for FC processing. According to the European Cultivated Potato Database [52], cv. Birgit is a novel German cultivar of table potatoes and it is not inclined to browning, while cv. Lady Claire is a common industrial cultivar mostly used in chips industry [53]. However, to our best of knowledge, there are no literature data on PAH contents in these two cultivars.

Results obtained in this work showed a significant influence of potato cultivar on the PAH contents in oils extracted from fried FCP. Light PAH fraction species data presented in Table 3 reveal significant differences in the contents of naphthalene, acenaphthene, fluorene, phenanthrene, benzo(a)anthracene, chrysene and pyrene determined in Birgit and Lady Claire potato cultivars. Overall, light PAH contents were higher $(p<0.01)$ in $c v$. Lady Claire samples. Furthermore, Lady Claire also contained higher levels of heavy PAH (Table 4), i.e., benzo(b)fluoranthene $(p<0.01)$, benzo(a)pyrene $(p=0.02)$ and benzo(g,h,i)perylene $(p<0.01)$, which values were $2.5-3.5$ fold higher than those measured for $\mathrm{cv}$. Birgit (0.06-0.22 $\mu \mathrm{g} \mathrm{kg}^{-1}, 0.08-0.18 \mu \mathrm{g} \mathrm{kg}-1$ and $0.19-0.57 \mu \mathrm{g} \mathrm{kg}^{-1}$, respectively). Similarly, PAH4 levels (Figure 2) were higher in cv. Lady Claire FCP $\left(1.09 \mu \mathrm{g} \mathrm{kg}^{-1}\right)$ compared to cv. Birgit $\left(0.38 \mu \mathrm{g} \mathrm{kg}^{-1}\right)$.

Total PAH content (Figure 3) was also significantly influenced by cultivar, with levels being twofold higher in cv. Lady Claire samples (12.53 vs. $6.56 \mu \mathrm{g} \mathrm{kg}^{-1}$ ).

Although there are no previously published results on comparison of PAH contents in different potato varieties, the effect of cultivar on the PAH intake and accumulation have been noticed for other crops, e.g., coffee and rice [54,55]. Differences in PAH uptake between various plants and plant parts have also been studied by Fismes et al. (2002) [56]. They found higher levels of PAH in whole tubers when compared to the peeled potatoes, which they explain by higher lipid contents in peels. In addition, PAH levels were also higher in carrots that have high lipid content and, consequently, greater potential to accumulate non-polar molecules. Even though original PAH content in fried FCP might have been somewhat diluted due to the higher oil uptake, greater PAH contamination found in cv. Lady Claire samples can therefore be explained by the higher lipid content of cv. Lady Claire tubers which was determined at $0.77 \%$ compared to $0.58 \%$ in cv. Birgit.

To further examine and visualise the interrelationship of determined differences in PAH species between cultivars included in this study, PCA was implemented (Figure 4). Based on the preliminary PCA, a total of 13 active variables with a communality value $\geq 0.5$ were selected. PCA run included 32 observations and identified two main factors with eigenvalues of 8.488 and 1.561, respectively, which accounted for $77.30 \%$ of total data variance. First factor (F1) represented $65.29 \%$ of total variance and very strongly positively correlated with the majority of light fraction PAH species and all components from the heavy fraction as well as with sums of total PAH and PAH4. Acenaphthene was the only light PAH that had a positive correlation with the second factor (F2) which was also positively correlated with one heavy PAH, i.e., benzo(a)-pyrene and also with the oil uptake. F2 accounted for $12.01 \%$ of total variance. Furthermore, from the observations (samples) layout on the factorial plane $(\mathrm{F} 1 \times$ F2) differential distribution can be noted. The $95 \%$ confidence ellipses were also plotted around the means and clearly show grouping of cv. Lady Claire samples in the positive and cv. Birgit samples in the negative levels of $\mathrm{F} 1$ which confirms previously drawn conclusions. 

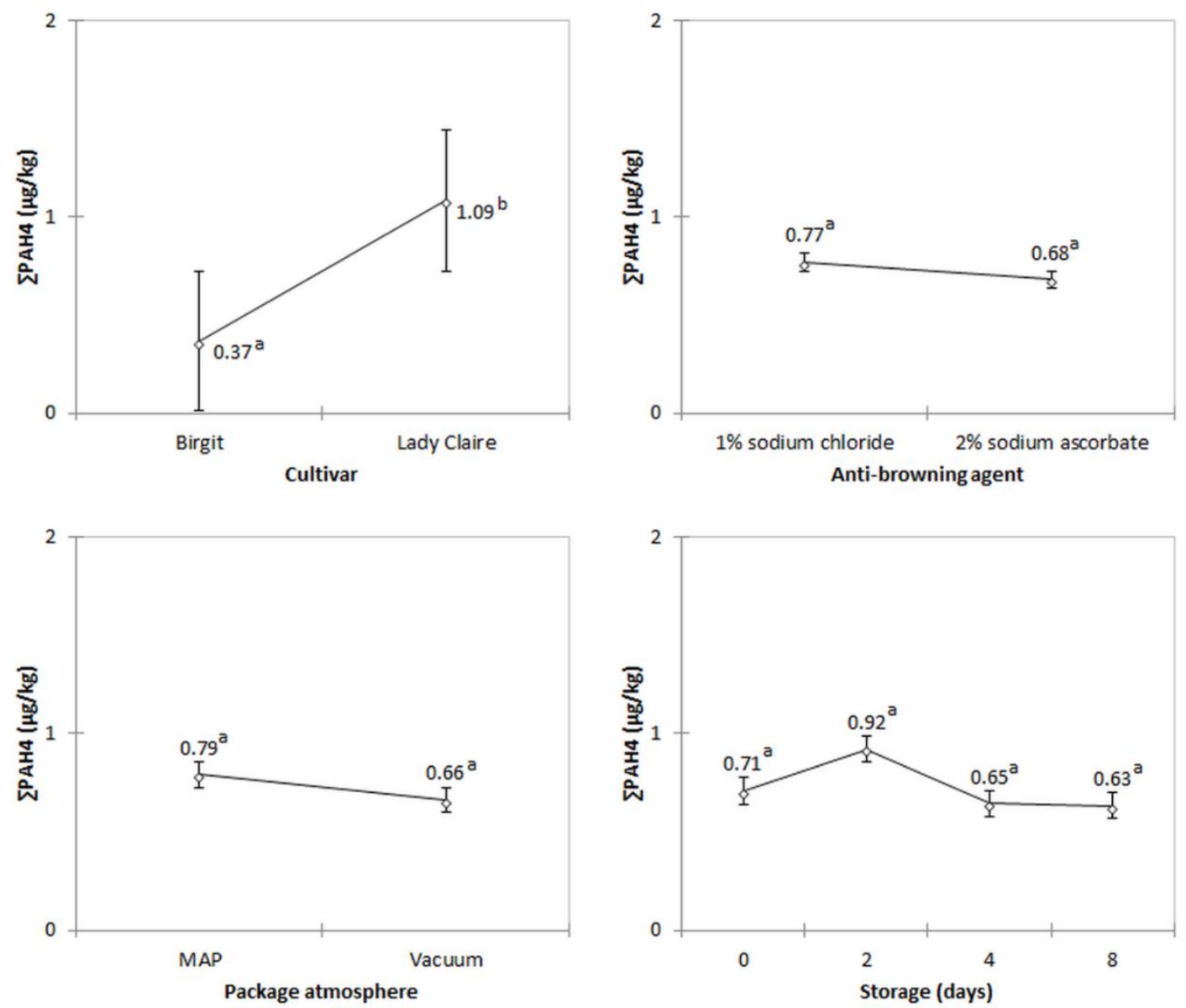

Figure 2. $\mathrm{PPAH} 4$ in fried fresh-cut potato as affected by the cultivar, anti-browning agent, packaging and storage duration. Results are expressed as mean \pm SE of $n=16$ for cultivars, anti-browning agents, package atmospheres and $n=8$ for days. Values with different letters are statistically different at $p \leq 0.05$.
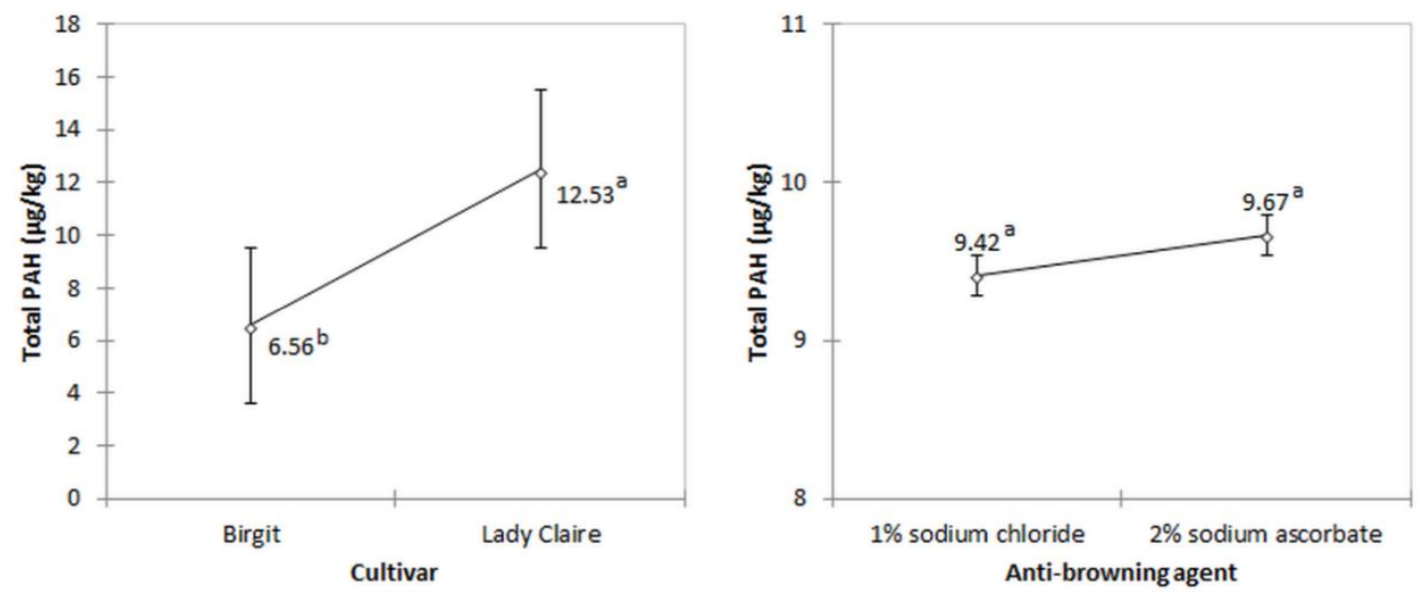

Figure 3. Cont. 

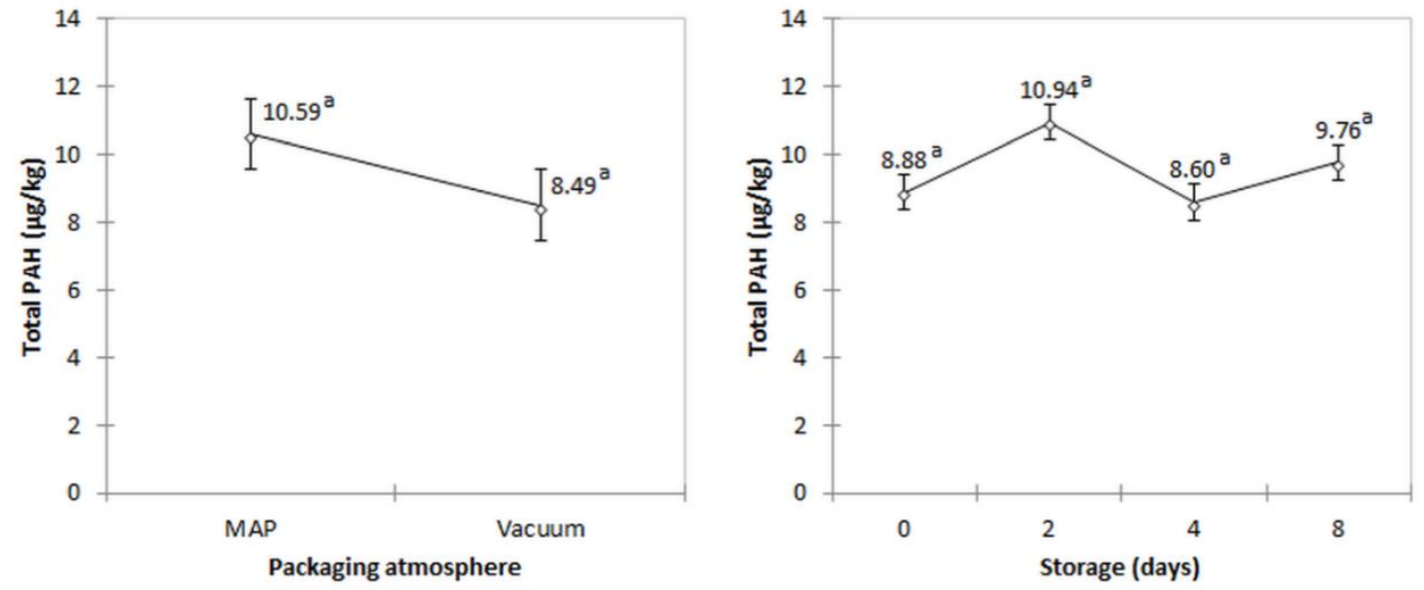

Figure 3. Total PAH in fried fresh-cut potato as affected by the cultivar, anti-browning agent, packaging and storage duration. Results are expressed as mean \pm SE of $n=16$ for cultivars, anti-browning agents, package atmospheres and $n=8$ for days. Values with different letters are statistically different at $p \leq 0.05$.
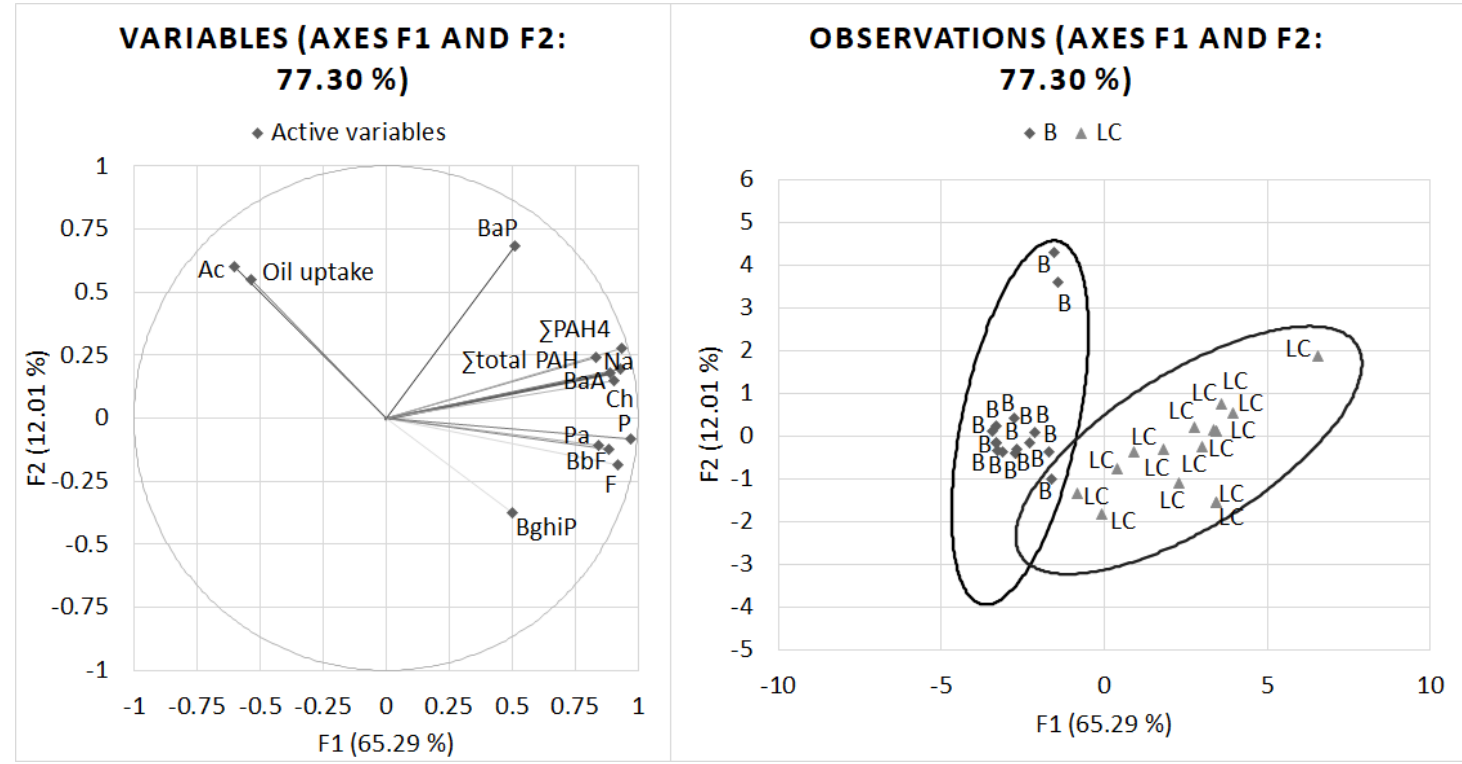

Figure 4. Principal components analysis (PCA)—Projection of active variables (Na-naphthalene, Ac-acenaphthene, F-fluorine, Pa-phenanthrene, P-pyrene, BaA-benzo(a)-anthracene, $\mathrm{Ch}$-chrysene, $\mathrm{BbF}$-benzo(b)-fluoranthene, $\mathrm{BaP}$-benzo(a)-pyrene, BghiP-benzo(g,h,i)-perylene) and observations (B-Birgit, LC-Lady Claire) on the factorial plane $(\mathrm{F} 1 \times \mathrm{F} 2)$.

\subsection{Effect of Processing}

As it was mentioned, fresh-cut processing of potatoes usually includes anti-browning agent treatment and modifications of the packaging atmosphere [7,57,58]. Anti-browning agents are used to control enzymatic browning through various mechanisms that either inhibit polyphenoloxidase activity and browning reaction or react with its products causing discoloration of formed dark pigments [59]. Sodium salts used in this study were chosen due to their ability to reduce the browning products and well-established GRAS status. Even though the type of anti-browning agent can have a significant effect on the metabolic activity and sensory attributes of FCP $[49,59]$, sodium chloride and sodium ascorbate solutions used in this work did not cause any significant changes to the content of PAH.

Furthermore, packaging solutions applied in this work, i.e., VP and MAP are, due to their inhibitory effect on foodborne pathogens, often used for FC products preservation and stabilization [60]. 
It has been shown that VP can extend shelf-life of FCP up to 7 days without any quality deterioration taking place [61] and that it is superior to MAP in the preservation of slices appearance [9]. Even though PAH4 and total PAH levels (Figures 2 and 3) were not influenced by processing, levels of some PAH species determined in this study were affected by the packaging atmosphere. Naphthalene, fluorene and pyrene (Table 3 ) were significantly lower in potato samples kept in $\operatorname{VP}(p=0.04, p=0.03$ and $p=0.02$, respectively) in comparison to the MAP ones. These differences could be supported by the results of Rocha et al. (2003) [61] which showed that VP of potatoes causes mechanical damage of the potato tissue and results in $25 \%$ decrease in firmness in the first day of storage. This cell destruction might have caused a more significant migration of PAH species to the frying oil and therefore lowered their contents in the fried FCP slices. Furthermore, naphthalene, fluorene, phenanthrene and benzo(a)pyrene (Table 4) were also affected by the interaction of cultivar and packaging atmosphere $(p=0.01, p=0.03$, $p=0.01$ and $p=0.02$, respectively). PAH levels were generally higher in cv. Lady Claire samples stored in MAP compared to the VP samples. Considering that cv. Lady Claire fresh potatoes had higher lipid content, this notion adds to the previous explanation of some PAH levels being decreased by the effect of vacuum.

Treated and packaged FCP were stored up to 8 days. This period was selected based on the results of Dite-Hunjek et al. (2020) [13] study which showed that basic quality and sensory properties of FCP remained preserved during 8 days of storage. As expected, storage duration (0-8 days) did not show any significant effect on the content of analysed PAH.

\section{Conclusions}

Results of this study showed that minimal processing did not increase the oil content of fried FCP. Among all analysed factors, only cultivar had a significant effect on the oil uptake which was higher in cv. Birgit potatoes. Compared to the cv. Lady Claire, cv. Birgit had higher tuber water content, consequently causing higher interchange of water with frying oil. Based on the comparison with the EU legal limitations, findings of the present study of benzo(a)pyrene and $\Sigma$ PAH4 levels up to 0.62 and $1.36 \mu \mathrm{g} \mathrm{kg}^{-1}$ respectively, confirmed previously established notion that PAH contamination in fried potatoes does not pose a direct health hazard to the consumer. Also, as PAH contamination from frying oil and PAH formation during frying process is negligible, environmental pollution is the most probable source of PAH in fried potato slices. Potato cultivar had a significant influence on the content of the majority of examined light and heavy PAH species with the exception of anthracene, fluoranthene, benzo(k)fluoranthene and dibenzo(a,h)anthracene. While the anti-browning treatment did not cause any changes in the PAH levels, naphthalene, fluorene, and pyrene were decreased by VP probably due to the mechanical damage of the potato tissue. No significant differences were determined between the PAH levels during storage, therefore regarding this parameter, storage of FCP produced with applied processing conditions can be safely achieved through the whole tested time span, i.e., up to 8 days. However, due to the potential cumulative exposure, certain caution must be advised. In addition, as risk assessment in FC products is presented not only by PAH levels, but also by other parameters such as microbial load, FCP production requires great attention focused on product's safety during the entire production process.

Author Contributions: Conceptualization, S.B. and B.L.; Data curation, S.B. and M.R.; Formal analysis, T.S., D.D.H. and M.O.; Project administration, B.L.; Supervision, B.L.; Validation, K.K.; Writing-original draft, S.B. and M.R.; Writing-review \& editing, D.Š. and B.L. All authors have read and agreed to the published version of the manuscript.

Funding: This research was funded by Croatian Science Foundation project (grant number IP-2016-06-5343).

Conflicts of Interest: The authors have declared no conflict of interest. 


\section{References}

1. Santeramo, F.G.; Carlucci, D.; De Devitiis, B.; Seccia, A.; Stasi, A.; Viscecchia, R.; Nardone, G. Emerging trends in European food, diets and food industry. Food Res. Int. 2018, 104, 39-47. [CrossRef] [PubMed]

2. Asioli, D.; Aschemann-Witzel, J.; Caputo, V.; Vecchio, R.; Annunziata, A.; Næs, T.; Varela, P. Making sense of the "clean label" trends: A review of consumer food choice behavior and discussion of industry implications. Food Res. Int. 2017, 99, 58-71. [CrossRef] [PubMed]

3. De Corato, U. Improving the shelf-life and quality of fresh and minimally-processed fruits and vegetables for a modern food industry: A comprehensive critical review from the traditional technologies into the most promising advancements. Crit. Rev. Food Sci. Nutr. 2019, 60, 1-36. [CrossRef]

4. Farina, V.; Passafiume, R.; Tinebra, I.; Palazzolo, E.; Sortino, G. Use of Aloe Vera Gel-Based Edible Coating with Natural Anti-Browning and Anti-Oxidant Additives to Improve Post-Harvest Quality of Fresh-Cut 'Fuji'Apple. Agronomy 2020, 10, 515. [CrossRef]

5. FAO. Faostat: Food and Agriculture Data; Food and Agriculture Organization of United Nations: Rome, Italy, 2018.

6. Bobo-García, G.; Arroqui, C.; Merino, G.; Vírseda, P. Antibrowning Compounds for Minimally Processed Potatoes: A Review. Food Rev. Int. 2019, 36, 1-18. [CrossRef]

7. Rocculi, P.; Galindo, F.G.; Mendoza, F.; Wadsö, L.; Romani, S.; Dalla Rosa, M.; Sjöholm, I. Effects of the application of anti-browning substances on the metabolic activity and sugar composition of fresh-cut potatoes. Postharvest Biol. Technol. 2007, 43, 151-157. [CrossRef]

8. Cabezas-Serrano, A.B.; Amodio, M.L.; Cornacchia, R.; Rinaldi, R.; Colelli, G. Suitability of five different potato cultivars (Solanum tuberosum L.) to be processed as fresh-cut products. Postharvest Biol. Technol. 2009, 53, 138-144. [CrossRef]

9. Beltrán, D.; Selma, M.V.; Tudela, J.A.; Gil, M.I. Effect of different sanitizers on microbial and sensory quality of fresh-cut potato strips stored under modified atmosphere or vacuum packaging. Postharvest Biol. Technol. 2005, 37, 37-46. [CrossRef]

10. Cantos, E.; Tudela, J.A.; Gil, M.I.; Espín, J.C. Phenolic compounds and related enzymes are not rate-limiting in browning development of fresh-cut potatoes. J. Agric. Food Chem. 2002, 50, 3015-3023. [CrossRef]

11. Tudela, J.A.; Espın, J.C.; Gil, M.I. Vitamin C retention in fresh-cut potatoes. Postharvest Biol. Technol. 2002, 26, 75-84. [CrossRef]

12. Wang, Y.; Naber, M.R.; Crosby, T.W. Effects of Wound-Healing Management on Potato Post-Harvest Storability. Agronomy 2020, 10, 512. [CrossRef]

13. Dite Hunjek, D.; Repajić, M.; Ščetar, M.; Karlović, S.; Vahčić, N.; Ježek, D.; Galić, K.; Levaj, B. Effect of anti-browning agents and package atmosphere on the quality and sensory of fresh-cut Birgit and Lady Claire potato during storage at different temperatures. J. Food Process. Preserv. 2020, 44, e14391. [CrossRef]

14. Stott-Miller, M.; Neuhouser, M.L.; Stanford, J.L. Consumption of deep-fried foods and risk of prostate cancer. Prostate 2013, 73, 960-969. [CrossRef] [PubMed]

15. de Boer, A.; Bast, A. Demanding safe foods-Safety testing under the novel food regulation (2015/2283). Trends Food Sci. Technol. 2018, 72, 125-133. [CrossRef]

16. Arslan, M.; Xiaobo, Z.; Shi, J.; Rakha, A.; Hu, X.; Zareef, M.; Zhai, X.; Basheer, S. Oil uptake by potato chips or French fries: A review. Eur. J. Lipid Sci. Technol. 2018, 120, 1800058. [CrossRef]

17. Todd, C.S.; Williams, D.M.; Guo, J. Characterization of the Distribution of Oil Uptake in French Fries. Micros. Today 2018, 26, 30-35. [CrossRef]

18. Arya, A.M.; Chandra, S.; Samsher, J.S.; Chauhan, N.; Kumar, T. Moisture loss and oil uptake kinetics in French fries (var. Kufri bahar) during frying in different oils and treatments. IJCS 2017, 5, 594-596.

19. Sirot, V.; Rivière, G.; Leconte, S.; Vin, K.; Traore, T.; Jean, J.; Carne, G.; Gorecki, S.; Veyrand, B.; Marchand, P. French infant total diet study: Dietary exposure to heat-induced compounds (acrylamide, furan and polycyclic aromatic hydrocarbons) and associated health risks. Food Chem. Toxicol. 2019, 130, 308-316. [CrossRef]

20. Singh, L.; Varshney, J.G.; Agarwal, T. Polycyclic aromatic hydrocarbons' formation and occurrence in processed food. Food Chem. 2016, 199, 768-781. [CrossRef] 
21. Hanedar, A.; Alp, K.; Kaynak, B.; Avşar, E. Toxicity evaluation and source apportionment of polycyclic aromatic hydrocarbons (PAHs) at three stations in Istanbul, Turkey. Sci. Total Environ. 2014, 488, 437-446. [CrossRef]

22. Abou-Arab, A.A.K.; Abou-Donia, M.A.M.; El-Dars, F.; Ali, O.I.M.; Hossam, A.G. Levels of polycyclic aromatic hydrocarbons (PAHS) in some Egyptian vegetables and fruits and their influences by some treatments. Int. J. Curr. Microbiol. App. Sci. 2014, 3, 277-293.

23. Samsøe-Petersen, L.; Larsen, E.H.; Larsen, P.B.; Bruun, P. Uptake of trace elements and PAHs by fruit and vegetables from contaminated soils. Environ. Sci. Technol. 2002, 36, 3057-3063. [CrossRef] [PubMed]

24. Wennrich, L.; Popp, P.; Zeibig, M. Polycyclic aromatic hydrocarbon burden in fruit and vegetable species cultivated in allotments in an industrial area. Int. J. Environ. Anal. Chem. 2002, 82, 667-690. [CrossRef]

25. Zhong, W.; Wang, M. Some polycyclic aromatic hydrocarbons in vegetables from northern China. J. Environ. Sci. Health Part A 2002, 37, 287-296. [CrossRef] [PubMed]

26. EU Regulation 835/2011. Commission Regulation (EU) No 835/2011 of 19 August 2011 Amending Regulation (EC) No 1881/2006 as Regards Maximum Levels for Polycyclic Aromatic; European Comission: Bruxelles, Belgium, 2011.

27. Dite Hunjek, D.; Pranjić, T.; Repajić, M.; Levaj, B. Fresh-cut potato quality and sensory: Effect of cultivar, age, processing, and cooking during storage. J. Food Sci. 2020. [CrossRef] [PubMed]

28. AOAC. Official Methods of Analysis: Changes in Official Methods of Analysis Made at the Annual Meeting. Supplement; Association of Official Analytical Chemists: Rockvilleu, MD, USA, 1990; Volume 15.

29. Purcaro, G.; Navas, J.A.; Guardiola, F.; Conte, L.S.; Moret, S. Polycyclic aromatic hydrocarbons in frying oils and snacks. J. Food Prot. 2006, 69, 199-204. [CrossRef]

30. Neđeral, S.; Pukec, D.; Škevin, D.; Kraljić, K.; Obranović, M.; Zrinjan, P. On-line DACC-HPLC analysis of polycyclic aromatic hydrocarbons in edible oils. Hrvat. Časopis Prehrambenu Tehnol. Biotehnol. Nutr. 2013, 8, 74-81.

31. Guideline, I.C.H.H.T. Validation of analytical procedures: Text and methodology Q2 (R1). In Proceedings of the International Conference on Harmonization, Geneva, Switzerland, 10 November 2005; Volume 11.

32. Krokida, M.K.; Oreopoulou, V.; Maroulis, Z.B. Water loss and oil uptake as a function of frying time. J. Food Eng. 2000, 44, 39-46. [CrossRef]

33. Ziaiifar, A.-M. Oil Absorption during Deep-Fat Frying: Mechanisms and Important Factors; AgroParisTech: Paris, France, 2008.

34. Elfnesh, F.; Tekalign, T.; Solomon, W. Processing quality of improved potato (Solanum tuberosum L.) cultivars as influenced by growing environment and blanching. Afr. J. Food Sci. 2011, 5, 324-332.

35. Oner, M.E.; Walker, P.N. Effects of processing conditions on quality of refrigerated potato strips. Trans. ASABE 2010, 53, 1661-1666. [CrossRef]

36. Krokida, M.K.; Oreopoulou, V.; Maroulis, Z.B.; Marinos-Kouris, D. Effect of pre-treatment on viscoelastic behaviour of potato strips. J. Food Eng. 2001, 50, 11-17. [CrossRef]

37. (EFSA), E.F.S.A. Findings of the efsa data collection on polycyclic aromatic hydrocarbons in food. EFSA J. 2007, 5, 33r.

38. EFSA. EFSA Opinion on Suitable Indicators for Both the Occurrence and Toxicity of Polycyclic Aromatic Hydrocarbons (PAHs) in Food; European Food Safety Administration: Parma, Italy, 2008.

39. Kumosani, T.A.; Moselhy, S.S.; Asseri, A.M.; Asseri, A.H. Detection of polycyclic aromatic hydrocarbons in different types of processed foods. Toxicol. Ind. Health 2013, 29, 300-304. [CrossRef] [PubMed]

40. Camargo, M.C.R.; Antoniolli, P.R.; Vicente, E. Evaluation of polycyclic aromatic hydrocarbons content in different stages of soybean oils processing. Food Chem. 2012, 135, 937-942. [CrossRef]

41. Shi, L.-K.; Zhang, D.-D.; Liu, Y.-L. Survey of polycyclic aromatic hydrocarbons of vegetable oils and oilseeds by GC-MS in China. Food Addit. Contam. Part A 2016, 33, 603-611. [CrossRef]

42. Cejpek, K.; Hajšlová, J.; Kocourek, V.; Tomaniová, M.; Cmolik, J. Changes in PAH levels during production of rapeseed oil. Food Addit. Contam. 1998, 15, 563-574. [CrossRef]

43. Molle, D.R.D.; Abballe, C.; Gomes, F.M.L.; Furlani, R.P.Z.; Tfouni, S.A.V. Polycyclic aromatic hydrocarbons in canola, sunflower and corn oils and estimated daily intake. Food Control 2017, 81, 96-100. [CrossRef]

44. Pandey, M.K.; Mishra, K.K.; Khanna, S.K.; Das, M. Detection of polycyclic aromatic hydrocarbons in commonly consumed edible oils and their likely intake in the Indian population. J. Am. Oil Chem. Soc. 2004, 81, 1131-1136. [CrossRef] 
45. Rose, M.; Holland, J.; Dowding, A.; Petch, S.R.G.; White, S.; Fernandes, A.; Mortimer, D. Investigation into the formation of PAHs in foods prepared in the home to determine the effects of frying, grilling, barbecuing, toasting and roasting. Food Chem. Toxicol. 2015, 78, 1-9. [CrossRef]

46. Bansal, V.; Kim, K.-H. Review of PAH contamination in food products and their health hazards. Environ. Int. 2015, 84, 26-38. [CrossRef]

47. Ashraf, M.W.; Salam, A. Polycyclic aromatic hydrocarbons (PAHs) in vegetables and fruits produced in Saudi Arabia. Bull. Environ. Contam. Toxicol. 2012, 88, 543-547. [CrossRef] [PubMed]

48. Kulhánek, A.; Trapp, S.; Sismilich, M.; Janků, J.; Zimová, M. Crop-specific human exposure assessment for polycyclic aromatic hydrocarbons in Czech soils. Sci. Total Environ. 2005, 339, 71-80. [CrossRef] [PubMed]

49. Ierna, A.; Pellegrino, A.; Di Silvestro, I.; Buccheri, M. Sensory and physico-chemical characteristics of minimally processed "early" potato tubers as affected by anti-browning treatments and cultivar. In Proceedings of the Acta Horticulturae; International Society for Horticultural Science (ISHS): Leuven, Belgium, 2016; pp. 229-236.

50. Pardo, J.E.; Alvarruiz, A.; Perez, J.I.; Gomez, R.; Varon, R. Physical-chemical and sensory quality evaluation of potato varieties (Solanum tuberosum L.). J. Food Qual. 2000, 23, 149-160. [CrossRef]

51. Amrein, T.M.; Bachmann, S.; Noti, A.; Biedermann, M.; Barbosa, M.F.; Biedermann-Brem, S.; Grob, K.; Keiser, A.; Realini, P.; Escher, F. Potential of acrylamide formation, sugars, and free asparagine in potatoes: A comparison of cultivars and farming systems. J. Agric. Food Chem. 2003, 51, 5556-5560. [CrossRef] [PubMed]

52. European Cultivated Potato Database. Available online: https://www.europotato.org/ (accessed on 19 December 2019).

53. Elmore, J.S.; Briddon, A.; Dodson, A.T.; Muttucumaru, N.; Halford, N.G.; Mottram, D.S. Acrylamide in potato crisps prepared from 20 UK-grown varieties: Effects of variety and tuber storage time. Food Chem. 2015, 182, 1-8. [CrossRef]

54. Tfouni, S.A.V.; Serrate, C.S.; Leme, F.M.; Camargo, M.C.R.; Teles, C.R.A.; Cipolli, K.M.; Furlani, R.P.Z. Polycyclic aromatic hydrocarbons in coffee brew: Influence of roasting and brewing procedures in two Coffea cultivars. LWT Food Sci. Technol. 2013, 50, 526-530. [CrossRef]

55. He, Y.; Xia, W.; Li, X.; Lin, J.; Wu, J.; Xu, J. Dissipation of phenanthrene and pyrene at the aerobic-anaerobic soil interface: Differentiation induced by the rhizosphere of PAH-tolerant and PAH-sensitive rice (Oryza sativa L.) cultivars. Environ. Sci. Pollut. Res. 2015, 22, 3908-3919. [CrossRef]

56. Fismes, J.; Perrin-Ganier, C.; Empereur-Bissonnet, P.; Morel, J.L. Soil-to-root transfer and translocation of polycyclic aromatic hydrocarbons by vegetables grown on industrial contaminated soils. J. Environ. Qual. 2002, 31, 1649-1656. [CrossRef]

57. Francis, G.A.; Gallone, A.; Nychas, G.J.; Sofos, J.N.; Colelli, G.; Amodio, M.L.; Spano, G. Factors affecting quality and safety of fresh-cut produce. Crit. Rev. Food Sci. Nutr. 2012, 52, 595-610. [CrossRef]

58. Calder, B.L.; Kash, E.A.; Davis-Dentici, K.; Bushway, A.A. Comparison of sodium acid sulfate to citric acid to inhibit browning of fresh-cut potatoes. J. Food Sci. 2011, 76, S164-S169. [CrossRef]

59. Rocculi, P.; Romani, S.; Gómez Galindo, F.; Dalla Rosa, M. Effect of minimal processing on physiology and quality of fresh-cut potatoes: A review. Food 2009, 3, 18-30.

60. Oliveira, M.; Abadias, M.; Usall, J.; Torres, R.; Teixidó, N.; Viñas, I. Application of modified atmosphere packaging as a safety approach to fresh-cut fruits and vegetables-A review. Trends Food Sci. Technol. 2015, 46, 13-26. [CrossRef]

61. Rocha, A.M.C.N.; Coulon, E.C.; Morais, A.M.M.B. Effects of vacuum packaging on the physical quality of minimally processed potatoes. Food Serv. Technol. 2003, 3, 81-88. [CrossRef]

Publisher's Note: MDPI stays neutral with regard to jurisdictional claims in published maps and institutional affiliations. 